\title{
Perception of Senior High School EFL Teachers in Papua, Indonesia towards Their Own Competence
}

\author{
Yulini Rinantanti \\ English Teaching Program of FKIP, Universitas Cenderawasih, Papua, Indonesia \\ Muhammad Asfah Rahman \\ English Education Department, Universitas Negeri Makassar, Makassar, Indonesia \\ Haryanto Atmowardoyo \\ English Education Department, Universitas Negeri Makassar, Makassar, Indonesia \\ Saidna Z. Bin-Tahir \\ English Education Department, Universitas Iqra Buru, Maluku, Indonesia
}

\begin{abstract}
This paper reports the competence of the English Foreign Language (EFL) Senior High School (SHS) teachers in Papua, Indonesia which sought to investigate the EFL SHS teachers' perception towards their own competence. This cross-sectional survey research design applied multistage sampling technique in determining the sample of the study. There were 159 EFL SHS teachers from six selected townships in Papua as the sample. The researchers employed questionnaire and interview as the instrument for collecting data. Data were analyzed utilizing descriptive statistics to run for frequencies and percentages. The result revealed that the EFL SHS teachers in Papua perceived that their teacher competence was good. As the majority of the respondents $(\mathbf{9 1 . 8 \%})$ contended that they possessed good competency and only a few of respondents $(8.2 \%)$ claimed that their competence was very good. None of the respondents asserted either they have poor or fairly good competence.
\end{abstract}

Index Terms-perception, EFL teacher, teacher competence

\section{INTRODUCTION}

In Indonesian, English is a foreign language and a compulsory subject taught to students from grade seven to tertiary level (Lauder, 2008; Mattarima \& Hamdan, 2011). English has even begun to be taught in the 4th grade of elementary school students as the prudence of the school (Indonesian Government Regulation, Number 28, 1990) or as a local content subject (Mappiase \& Sihes, 2014). Although English in Indonesian schooling is formally taught to students from grade 7 to university level, the students' English proficiency, in general, is considered relatively low. Students graduated from schools or universities are still unable to show their ability to communicate in English (written and orally) intelligibly (Lengkanawati, 2005). Let alone graduated students from schools or colleges in Papua. Possessing good score in English does not guarantee that students are able to communicate in English (Rinantanti \& Suhirman, 2017).

There are numerous causation factors to the lack success in EFL instruction in Indonesian schooling (Dardjowidjoyo, 2000; Yuwono, 2005; Kirkpatrick, 2007; Soepriyatna, 2012). These factors include the low motivation of students in learning English, over-crowded English learning classes, inadequate facilities and learning resources, the continuously changing curriculum, and less qualified or less competent of the English teachers (Hamied, 2001; Bradford's, 2007; Kirkpatrick, 2007; Sulistiyo, 2009; Kassing, 2011).

Given the factors that led to the less successful learning of English aforementioned, the writers assume that the less competent of the English teachers were the most crucial factor, especially in Papua province (Rinantanti, 2013). Papua is not very different from Maluku province in which facing complicated issues related to the teachers' competence (BinTahir \& Rinantanti, 2016). As the teachers' competence affect the quality of the teachers' performances or instructions and it is also a determinant of the student success (Soepriyatna, 2012). With regards to this, Jalal et al (2009:7) contend that "good quality of teachers can produce good quality of learners, and then the poor quality of teachers can contribute to the poor achievement of students." As the English proficiency of graduate students in Papua is relatively low, it is necessary to conduct a study to overcome this issue. Considering this, for the initial steps, investigating the perception of the EFL SHS teachers in Papua towards their own competence is necessary as their perception may steer and direct the teachers in their teaching performance. 


\section{LITERATURE REVIEW}

\section{A. Concept of Competence and Competency}

Competence and competency are interconnected words which have mingling meanings (Mulder, 2007). Competence ascribes to the Latin word competentia which means the deed, the enlightenment, skills, and responsibility in conducting something (Gniteki, 2005). Deakin (2008: 42) defines competence as a complex blend of knowledge, skills, understanding, values, attitudes, and desire of someone to do something in a certain domain effectively. Richards and Schmidt (2002: 94) define it as a description of the skills, knowledge, and behavior that a person needs to achieve effective performance in his or her job activities. So the word competence contains three main elements to indicate the effectiveness of a performance knowledge, skills, and attitudes. Knowledge is an awareness of a material or information that a person acquires through his or her experience, books or other media. Skill is a person's ability to perform certain tasks whereas the attitude shows the person willingness (Soepriyatna, 2012).

Competency according to Trinder (2008) is the standard of achieving in various levels of work. Gupta (1999: 24) defines competency as a person's ability in applying knowledge and skills to produce the expected product. Hence, competence refers to a person's knowledge and abilities; competency, on the other hand, refers to the description of how something should be done. Competency refers to the feature of knowledge, skills, and experience required in doing the job. In other words, it is the ability of someone to apply his/her knowledge and skill to produce a required outcome. So competency is a part of competence.

\section{B. Teacher Competence and Competency}

Teacher competence (henceforth TC) or teacher competency is a concept used in relation to educational contexts since the emerging of education reform throughout the glove (Mulder, 2007). TC is defined as "statement about what teachers are supposed to know and be able to do" (Bailey, 2006: 210). Soepriyatna defines teacher competence as "a description of skills, knowledge, and behaviors required by teachers to perform effective teaching" (2012: 38). Based on aforementioned definitions, it implies that teachers must have the knowledge, skills, and attitude of being effective and successful teachers or competent teachers. Hence, not everyone can be a teacher (Rinantanti, 2015) as teaching is an intricate prodigy. It takes into account a wide range of personality traits, professional abilities and specific knowledge (Cole \& Chan, 2009).

A good teacher must have the basic knowledge for the teacher. They are the knowledge of the subject, pedagogical in general, curriculum and pedagogical content, the learners and their characteristics, educational context and educational goals (Shulman, 1987). Teachers must know the subject and how to teach it, the students and how they learn, how to create lesson plans, evaluate their instruction, communicate effectively to students, create and maintain a safe, fun, and challenging learning environment, manage their classes, constantly improve their professional knowledge and teaching, and active in the professionalism activities (Murray, 2009).

With regard to the language teachers in order to be able to teach the language effectively, teachers need to have "language specific competence," or good language proficiency factors, the role of content knowledge, teaching skills, contextual knowledge, the language teachers' identity, learner-focused teaching, pedagogical reasoning skills, theorizing from practice and membership of community practice as well as professionalism (Richards, 2011: 3). Teacher competence includes pedagogical, personality, social, professional and language proficiency competence (UURI No. 14, 2005).

\section{Perception}

Perception has a very close relationship with the attitude. Perception deals with the use of mind or senses to understand a person's surrounding. Attitude, on the other hand, is the person's feeling or a way of thinking about something based on their perception (Pickens, 2005).

Perception is the basis for understanding individual differences, as for how people perceive something will affect how people behave (Cillessen \& Lafonta, 2002: Lópes, 2010). Teachers' attitude is the reflection of their perception and their perception can guide and set their sights on their own teaching (Artini, 2010). Teachers' instructions are related to their perception of teaching and learning and their perception often determines their decisions and affects many aspects of classrooms such as the interactions, activities, assessment, and students' engagement (Zhu \& Wang, 2014; Stipek et al., 2001).

\section{METHOD}

This study attempted to describe the extent to which the EFL SHS teachers in Papua, Indonesia perceive their own competence in the present time, hence applying a cross-sectional survey research design was considered suitable. Survey research design is typically used to describe preferences, attitude, opinion, and perception of people of interest to the researcher(Latief, 2013; Ary, et al, 2007; Cohen, et al, 2007; Postlethwaite, 2005). In the cross-sectional survey data are collected one by one at a time (Creswell, 2010, Trochim, 2006).

Multistage random sampling technique was adopted to determine the sample of this study. The sample of this study (50\% of the population) was 159 EFL SHS teachers derived from six selected townships in Papua province. In 
collecting data the researchers applied self-constructed four-point Liker-type scale questionnaire and interview. The questionnaire has been piloted to 33 non-sample EFL SHS teachers to test the validity and the internal consistency of the items. The items were valid as the calculated of the $r$ value were greater than the $r$ table $(0.449)$. The result of reliability testing through Cronbach's Alpha Split-half technique value was 0.82 . The interviews were used as the supporting data. Data were analyzed using the descriptive statistical method to run for the frequencies and percentages.

\section{RESULTS AND DisCUSSIONS}

\section{A. Results}

The Perceptions of EFL SHS teachers in Papua towards their own level of competence was measured using questionnaire that consists of 50 items of statements covering the dimension of the pedagogical competence which encompasses of 26 items, the dimension of personal competence consists of 6 items of statements and so does the dimension of social competence, and the dimension of professional competence which consists of 12 items of statements. The finding presented based on the dimensions.

\section{The Pedagogical Competence of the EFL SHS Teachers}

The dimension of the teachers' perception towards their pedagogical competence was measured using a questionnaire consisting of 26 items of the statement. The lowest score for each statement was 1 and the highest score was 4 so that the theoretical score was between 26 and 104. The minimum score of 26 exists if the respondents gave an answer choice 1 for each of statement and the maximum score of 104 exists when the respondents gave an answer choice 4 for every statement.

Data of the pedagogical competence dimension were then presented in frequency distribution list within 4 categories. The tendency of frequency distribution score of the EFL SHS teachers' pedagogical competence can be seen in table 1 below.

TABLE 1.

THE FREQUENCY AND PERCENTAGE DISTRIBUTION OF TEACHERS’ PEDAGOGICAL COMPETENCE

\begin{tabular}{l|l|l|l}
\hline Interval & Classification & Frequency & Percentage $(\%)$ \\
\hline $26-46$ & Poor & 0 & 0 \\
\hline $47-66$ & Fairly Good & 0 & 0 \\
\hline $67-86$ & Good & 122 & 76.7 \\
\hline $87-104$ & Very Good & 37 & 23.2 \\
\hline Total & 159 & 100 \\
\hline
\end{tabular}

Table 1 indicates the frequency, percentage, and classification of the EFL SHS teachers' perception towards their own level of pedagogical competence. Based on the table, it can be said that the teachers' pedagogical competence was perceived of being acceptable. As most of the respondents (76.7\%) stated that their pedagogical competence was good, while the rest of the respondents $(23.2 \%)$ stated that their pedagogical competence was very good. The teachers' perception towards their own pedagogical competence can be illustrated in the following figure.

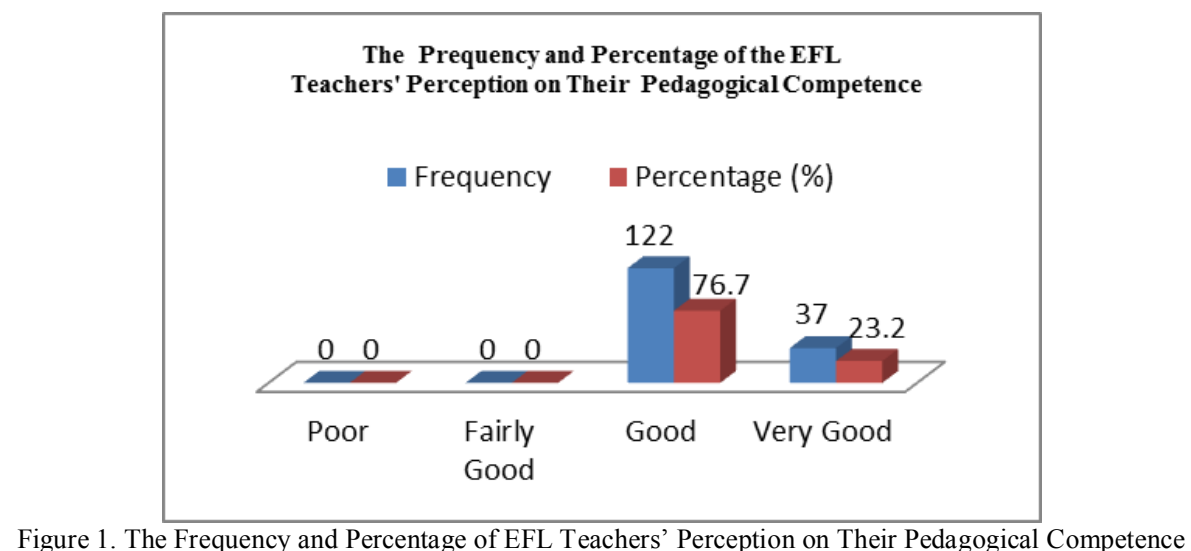

\section{The Personality Competence of the EFL SHS Teachers}

The dimension of the teachers' perception towards their personality competence was measured using a questionnaire consisting of 6 items of the statement. The lowest score for each statement was 1 and the highest score was 4 so that the theoretical score of this dimension was between 6 and 24. The minimum score of 6 occurs if the respondent gave an answer 1 for each of statement and the maximum score of 24 occurs if the respondent gave an answer 4 for each statement.

Data of the personality competence dimension were then presented with the frequency distribution list within 4 categories. The tendency of the frequency distribution score of the personality competence of the teacher can be seen in the following table. 
TABLE 2.

THE FREQUENCY \& PERCENTEGE DISTRIBUTION OF THE TEACHERS’ PERSONALITY COMPETENCE

\begin{tabular}{l|l|l|l}
\hline Interval & Classification & Frequency & Percentage $(\%)$ \\
\hline $6-10$ & Poor & 0 & 0 \\
\hline $11-15$ & Fairly Good & 0 & 0 \\
\hline $16-20$ & Good & 71 & 44.6 \\
\hline $21-24$ & Very Good & 88 & 55.4 \\
\hline Total & 159 & 100 \\
\hline
\end{tabular}

Table 2 indicates the frequency, percentage and the classification of the EFL SHS teachers' perception towards their own level of personal competence. From the table, it can be seen that the teachers' personality competence was great. Because more than $55 \%$ of the respondents perceived that their personality competence was very good and $44.6 \%$ of respondents perceived that it was good. There was no respondent stated either having poor or adequate competence. The personality competence distribution of the EFL teachers have can be illustrated in the following figure.

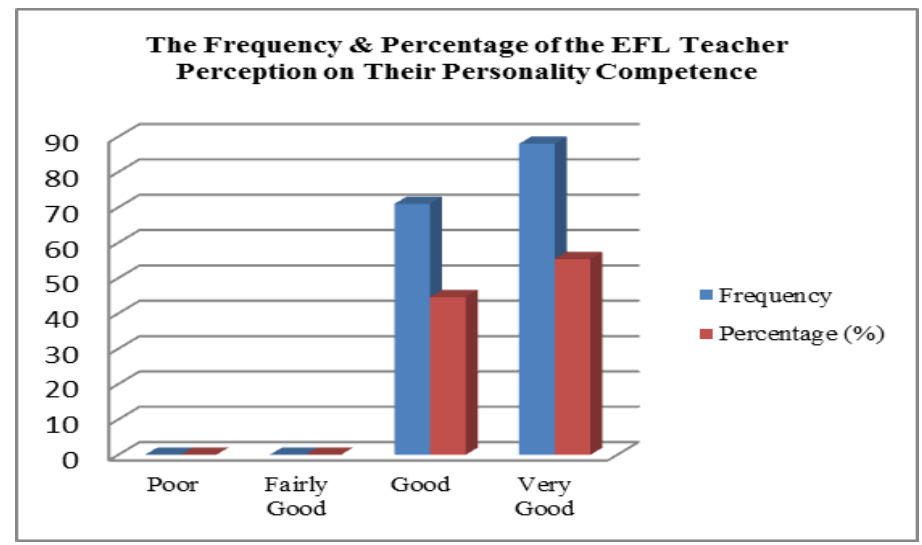

Figure 2. The Frequency and Percentage of the EFL Teachers' Perception on Their Personality Competence.

\section{The Social Competence of the EFL SHS Teachers}

The dimension of the teachers' perception towards their social competence was measured using a questionnaire consisting of 6 items of the statement. The lowest score for each statement was 1 and the highest score was 4 so that the theoretical score of this dimension was between 6 and 24. The minimum score of 6 occurs when the respondent gave an answer 1 for each of statement and the maximum score of 24 occurs when the respondent gave an answer 4 for each statement.

Data of the social competence dimension were then presented with the frequency distribution list within 4 categories. The tendency of the frequency distribution score of the social competence of the teacher can be seen in the following table.

TABLE 3.

THE FREQUENCY \& PERCENTAGE DISTRIBUTION OF THE TEACHERS' SOCIAL COMPETENCE

\begin{tabular}{l|l|l|l}
\hline Interval & Classification & Frequency & Percentage $(\%)$ \\
\hline $6-10$ & Poor & 0 & 0 \\
\hline $11-15$ & Fairly Good & 1 & 0.6 \\
\hline $16-20$ & Good & 141 & 88.6 \\
\hline $21-24$ & Very Good & 17 & 10.6 \\
\hline Total & 159 & 100 \\
\hline
\end{tabular}

Table 3 shows the frequency, percentage and the classification of the EFL SHS teachers' perception towards their social competence. Based on this table, it can be asserted that the social competence of the teacher was good. From 159 respondents, there were only $0.6 \%$ of the respondent who stated that their social competence was desirable. Less than $11 \%$ of respondents stated that their social competence was marvelous and the rest of respondents $(88.6 \%)$ claimed that they have good social competence. The teachers' perception towards their social competence can be displayed in the following figure. 


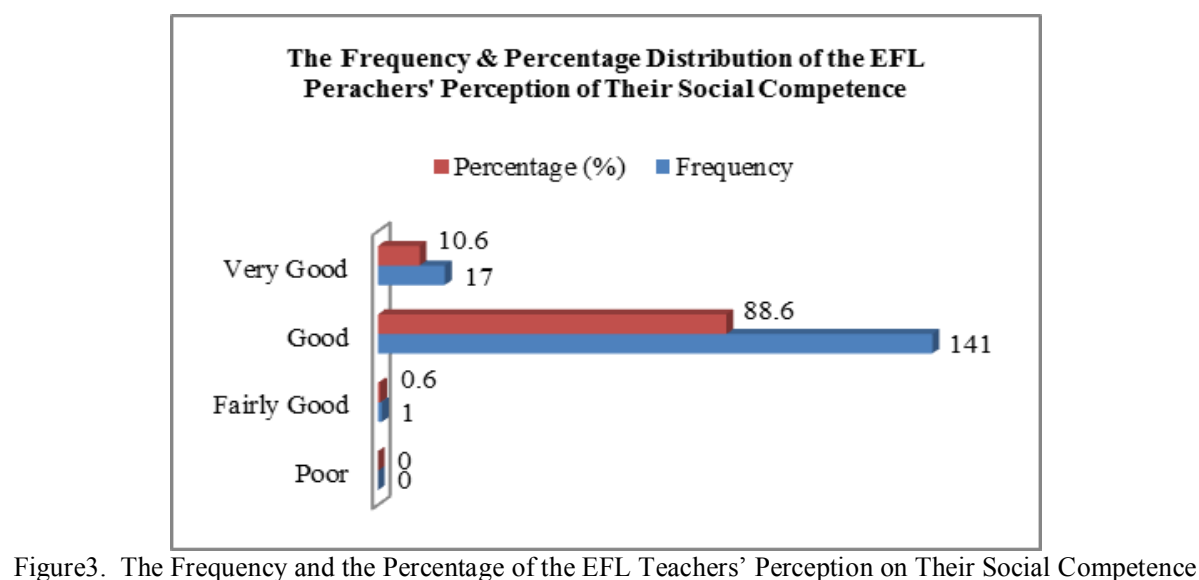

\section{The Professional Competence of the EFL SHS Teachers}

The dimension of the teachers' perception towards their professional competence was measured using a questionnaire consisting 12 items of the statement. The lowest score for each statement was 1 and the highest score was 4 so that the theoretical score of this dimension is between 12 and 48. The minimum score of 12 occurs if the respondent gave an answer 1 for each of statement and the maximum score of 48 occurs if the respondent gave an answer 4 for each statement.

Data the professional competence dimension were then presented with the frequency distribution list within 4 categories. The tendency of the frequency distribution score of the professional competence of the teacher can be seen in the following table.

TABLE 4.

THE FREQUENCY \& PERCENTAGE DISTRIBUTION OF THE TEACHERS' PROFESSIONAL COMPETENCE

\begin{tabular}{l|l|l|l}
\hline Interval & Classification & Frequency & Percentage $(\%)$ \\
\hline $12-21$ & Poor & 0 & 0 \\
\hline $22-31$ & Fairly Good & 2 & 1.2 \\
\hline $32-40$ & Good & 139 & 87.4 \\
\hline $41-48$ & Very Good & 18 & 11.3 \\
\hline Total & 159 & 100 \\
\hline
\end{tabular}

Table 4 indicates the frequency, percentage and the classification of the EFL SHS teachers' perception towards their professional competence. Based on the table, it can be asserted that the professional competence of the EFL SHS teacher was great. From 159 respondents, there were 18 (11.3\%) respondents stated that their professional competence was very good. Even though $2(1.2 \%)$ respondents stated that theirs are not so good, but the majority (139 or $77.4 \%)$ of the respondents claimed that theirs are good. The teachers' perception towards their professional competence can be displayed in the following figure.

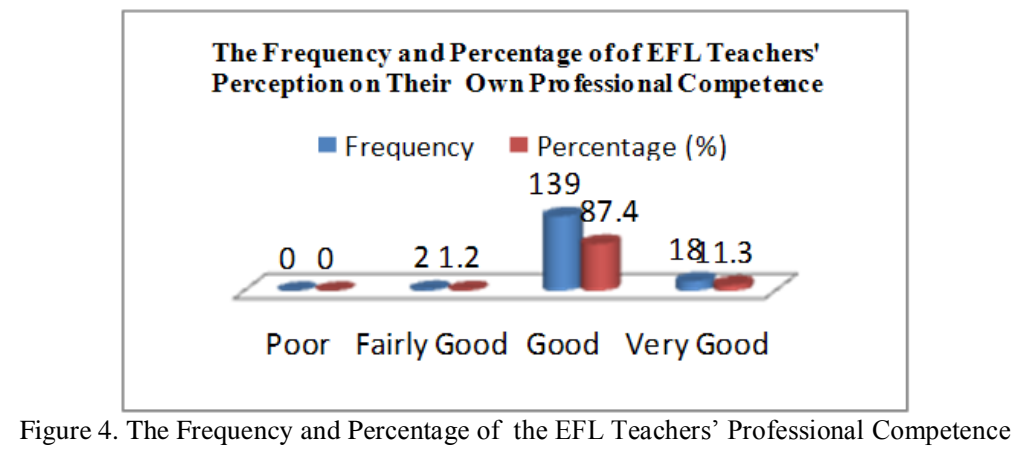

The EFL SHS teachers' perception towards their teacher competence in a whole was measured using a questionnaire which consists of 50 items of statements. The lowest score of each statement was 1 and the highest score was 4 so that the theoretical score was between 50 and 200. The minimum score of 50 exists when the respondents gave an answer 1 for each of the statement and the maximum score of 200 exists when the respondent gives an answer 4 for each of statement.

Data from the questionnaire were presented in frequency distribution list within 4 categories. The tendency of the frequency distribution score of the EFL teachers' perception towards their competence can be seen in table 5 below. 
TABLE 5.

THE FREQUENCY \& PERCENTAGE DISTRIBUTION OF THE TEACHERS' PERCEPTION ON THEIR COMPETENCE

\begin{tabular}{l|l|l|l}
\hline Interval & Classification & Frequency & Percentage $(\%)$ \\
\hline $50-90$ & Poor & 0 & 0 \\
\hline $91-130$ & Fairly Good & 0 & 0 \\
\hline $131-170$ & Good & 146 & 91.8 \\
\hline $171-200$ & Very Good & 13 & 8.2 \\
\hline Total & 159 & 100 \\
\hline
\end{tabular}

Table 5 indicates the frequency, percentage, and classification of SHS EFL teachers' perception towards their own competence. Even though based on separate dimensions of this variable there were considerable amount of respondents who claimed that they were excellence on certain dimension, for instance on their personality competence (more than $50 \%$ ), on their pedagogical competence $(23.2 \%)$, on their social competence $(10.6 \%)$, and on their professional competence $(11.3 \%)$, in general however, the teachers competence cannot be stated that it was very good. As the majority of the respondent $(91.8 \%)$ stated that the competency that they possessed was good and only a few of respondents claimed that they had a very good competence. The teachers' perception towards their own competence than can be illustrated in the figure bellow.

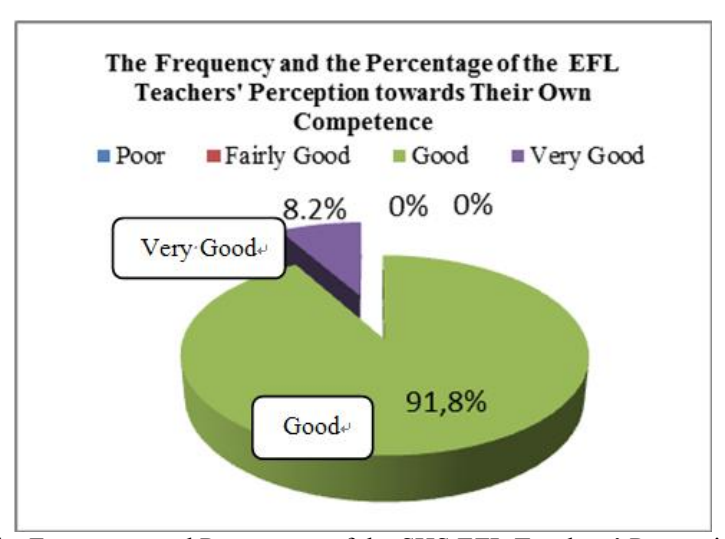

Figure 5 The Distribution of the Frequency and Percentage of the SHS EFL Teachers' Perception towards Their Competence

\section{B. Discussions}

This study revealed that the perception of EFL SHS teacher in Papua towards their pedagogical competence was good. The teachers' knowledge of their students and their characteristics reached the highest mean score of 3.66, followed by the ability of the teacher in designing the lesson plans and using the result of assessment for various aims with the means score of 3.53 and 3.37 respectively. From the interview found that teachers believed that knowing their students was pivotal (Shulman, 1987; Murray, 2009). It indicates the teachers' awareness that it benefits teachers in making suitable lesson plans, selecting and developing the suitable teaching material, as well as designing the classroom activities that engage students in learning (Richards, 2011). Without understanding the background of the students, the teachers will not certainly able to make the suitable teaching preparation and run effective instructions.

With regard to their personality competence, teachers perceived it as very good. Teachers felt that being proud and confident to be the English teacher is mandatory. It reached the highest mean score of 3.59, followed by behaving honestly, humanly, wisely and firmly reached the mean score of 3.33. Being proud to be teachers was necessary (Bhargawa \& Pathy, 2011; Zhu \& Wang, 2014). It can generate a sense of joy and triggers teachers to do things as best as they could in carrying out their duties. The teacher also realized that upholding the teaching profession code was imperative. As it was a set of moral principle and norm that underlie the implementation of the teachers' professional duties and services in relation to students, parents, colleges, and professional organization as well as the government in accordance with religious, educational, ethical and humanitarian values.

On the subject of the teachers' social competence, the teacher perceived it as good. Teachers ascertained that they have to be objective and do not discriminate students (Bhargawa \& Pathy, 2011). Treating students fairly will create the best learning atmosphere and then this will increase the student motivation to learn. Competent teachers have to be able to communicate well with students, colleges, parents, and communities. Social interaction is absolutely necessary for teachers (Magelinskaite, Kepalaite, \& Legkauskas, 2014).

As for the professional competence, the teacher perceived that their ability to communicate in English both orally and written, productive and receptive skills within all communication aspect was the best with the mean score of 3.98 , followed by mastering the standard and core competencies of teaching English at SHS with the mean score of 3.96. The EFL SHS teachers in Papua were fully aware that mastering the material, the concept, the structures of the language, and the scientific approaches that support the teaching was absolutely indispensable. Similarly, to the mastery of standard competencies and core competencies of the English subject. Teachers must be able to develop teaching material creatively, develop their professionalism in sustainable reflective action, and utilizing ICT to support their 
instruction and develop personally. According to Hilferty (2009), the teachers' professional competence dimension was the core competence of the teacher because it encompasses both pedagogical competence dimension and the knowledge of the subject being taught.

\section{CONCLUSION}

Based on the finding and the discussion above, it can be concluded that the perception of EFL SHS teachers in Papua toward their competence was commendable. It is more than $90 \%$ of the EFL SHS teacher respondents contended that their competence was good. The EFL teachers were fully aware that possessing, internalizing, mastering and actualizing the teacher competence in accomplishing their professional responsibilities are mandatory. This study has an important theoretical and practical contribution to teachers' professional development. EFL teachers with such awareness logically should have excellent competencies. Therefore, it is necessary for conducting in-depth research on how these teachers perceptions can steer and direct their instructions.

\section{REFERENCES}

[1] Artini, L.P. (2010). Theories of English as a Foreign Language Teaching and Learning. Singaraja: Ganesha University Education.

[2] Ary, D., Jacobs, L. C., \& Sorensen, C. (2007). Introduction to Research Education. (8th Ed.). Belmont: Wadsworth

[3] Bailey, M. K. (2006). Language Teacher Supervision: A case-based approach. Cambridge: Cambridge University Press

[4] Bin-Tahir, S. Z., \& Rinantanti, Y. (2016). Multilingual Lecturers' Competence in English Teaching at the University of Iqra Buru, Indonesia. Asian EFL Journal, 5, 79-92

[5] Bransford, J.D., Brown, A, L., \& Cocking, R.R. (eds). (1990). How People Learn: Brain, Mind, Experience, and school. Washington, DC: National Academic Press.

[6] Cillessen, A.H.N., \& Lafontana, K.M. (2002). Children's perceptions of popular and unpopular peers: A multi-method assessment. Developmental Psychology, 38(5), 635 - 647.

[7] Cohen, L. Manion, L. \& Morrison, K.(2007). Research Methods in Education (6th Eds.) New York: Routledge

[8] Cole, P. G., \& Chan, L. K. S. (2009). Teaching Principles and Practice, (2 Ed.). New South Wales: Prentice Hall.

[9] Creswell, J. W. (2010). Research Design Qualitative, Quantitative, and Mixed Methods. (3 ${ }^{\text {rd }}$ Eds.). California: Sage.

[10] Dardjowidjojo, S. (2000). English teaching in Indonesia. EA Journal, 18 (1), 22-30.

[11] Gnitecki, J. (2005). Competence in Theory and Practice. Basingstoke: Macmillan.

[12] Gupta, K. (1999). A practical guide for need assessment. San Fransisco: John Wiley \& Sons. Inc.

[13] Hamied, F. A. (2001). English language education in Indonesia. A paper presented at the East-West Center and Ohana Foundation Workshop on Increasing Creativity and Innovation in English Language Education, Honolulu, Hawaii.

[14] Jalal, F., Samani, M., Mae, C.C., Steverson, R. Ragate, B.A., \& Nagara, D.S. (2009). Teacher Certification in Indonesia: A Strategy for teacher quality improvement. Jakarta: Departement Pendidikan Nasional.

[15] Kassing, R. B. (2011). Perceptions of motivational teaching strategies in an EFL classroom: The case of a class in a private university in Indonesia. Unpublished Master Thesis. Victoria University of Wellington.

[16] Kirkpatrick, A. (2007). Teaching English across Culture. What do English Language Reachers Need to Know How to Teach English? EA Journal, 23(2), 21-36.

[17] Lauder, A. (2008). The Status and Function of English in Indonesia: A Review of Key Factor. Makara, Sosial Humaniora, 12(1), 9-20.

[18] Latief, M. A. (2013). Research Methods on Language Learning an Introduction. Malang: UM Press.

[19] Lengkenawati, N. S. (2005). EFL teachers' competence in the context of English curriculum 2004: Implication for EFL teacher education. TEFLIN Journal, 16(1), 79 - 92.

[20] Lópes, C. (2010). Moral responsibility and confidence as factor that influence teacher involvement in educational change. PROFILE Issues in Teachers' Professional Development. 12(1), 63-78.

[21] Mappiasse, S.S. \& Sihes, A. J. B. (2014). Evaluation of English as a Foreign Language and Its Curriculum in Indonesia: A Review. English Language Teaching. Canadian Center of Science and Education. 7 (10), 14-29.

[22] Mattarima, K., Hamdan, A.R. (2011). The Teaching Constrain of English as a Foreign Language in Indonesia: The Context of School Based Curriculum. Sociohumanika, 4(2), 287-300.

[23] Mulder, M. (2007). Introduction to the Special Issue on Competence. Competence-the essence and use of concept in IEVT. European Journal of Vocational Training. 40(1), 5-21.

[24] Murray, J. (2009). Teacher Competencies in the Post-Method Landscape: The Limits of Competency-Based Training in TESOL Teacher Education. Macquarie University Journal. 24(1), 17-29.

[25] Peraturan Pemerintah Republik Indonesia (Indonesian Government Regulation) No. 28, (1990) about Basic Education.

[26] Pickens. J. Attitudes and Perceptions. In Borkowski, N. (Eds.). (2005). Organizational Behavior in Health Care. Mississauga: Jones \& Bartlett Publisher.

[27] Postlethwaite, T. N. (2005). Educational Research: Some Basic Concepts and Terminology. Paris: International Institute for Educational Planning.

[28] Richards, J. C., Schmidt, R. (2002). Dictionary of language teaching and applied linguistics, ( $3^{\text {rd }}$ Ed). London: Longman.

[29] Richards, J. C. (2011). Competence and Performance in Language Teaching. Cambridge: Cambridge University Press.

[30] Rinantanti, Y. (2013). English as an International Language in Relation to the Teaching of Culture in EFL Classroom in Papua. Proceeding of $1^{\text {st }}$ International Conference on Language Teaching Material. Universitas Tanjungpura-Pontianak (Indonesia). 132-147. 
[31] Rinantanti, Y. (2015). Attitude toward Autonomy in Learning English: A Case in Cenderawasih University Papua, Indonesia. Asian EFL Journal/ Professional Teaching Articles. August (86), 90-108.

[32] Rinantanti, Y. \& Suhirman, L. (2017). Mapping of the Competence of SHS Students in English Subject in Sarmi and Mamberamo Raya Regencies Papua, Indonesia. The Asian EFL Journal. TESOL Indonesia International Conference Edition, Vol.10. Pp. 93-111.

[33] Shulman, L. (1987). Knowledge and teaching: Foundations of the new reform. Harvard Educational Review, 57(1), 1-22.

[34] Sulistiyo, U. (2009). Learning English in an Indonesian University: A study of learners' preferred activities. La Trobe University.

[35] Soepriyatna, S. (2012). Investigating and assessing competence of high school teachers of English in Indonesia. Malaysian Journal of ELT Research, 8(2), 38-49.

[36] Stipek, D. J. Givvin, K. B., Salmon, J.M. \& MacGyvers, V.L. (2001). Teacher's beliefs and practices related to Mathematics Instruction. Teaching and Teacher Education, 17, 213-226.

[37] Trinder, J.C. (2008). Competency Standards-A Measure of the Quality of a Workforce. The International Archives of the Photogrammetry, Remote Sensing and Spacial Information Science. XXXVII. B6a.

[38] Trochim, W. M. (2006). The Research Methods Knowledge Base. (2nd Eds.). Cincinnati: Atomic Dog Publishing.

[39] UU RI (Indonesian's Low of Teacher \& Lecturer No. 14, 2005.

[40] Yuwono, G. (2005). English language teaching in decentralized Indonesia: Voices from the less privileged schools. Paper presented at the AARE 2005 International Education Research Conference, The University of Sydney, Sydney, NSW. P. 1-19.

[41] Zhu, C. \& Wang, D. (2014). Key Competencies and Characteristics for Innovative Teaching among secondary School Teachers: a Mixed-Methods Research. Asia Pacific Education Review, 15 (2), 299-311.

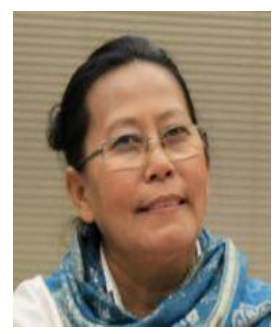

Yulini Rinantanti was born in Kediri, East Java Indonesia on July 22, 1963. She is currently a doctoral student at English Education Department of State University of Makassar, Indonesia. She completed her bachelor degree (Dra.) in English teacher education from Cenderawasih University in Jayapura, PapuaIndonesia in 1988 and obtained her master degree (M.Ed.) in tefl from James Cook University in Townsville, Queensland-Australia in 2001.

She is a lecturer at English Teaching Program of Faculty of Teacher Training and Education, Cenderawasih University-Jayapura, Papua-Indonesia. She has been a presenter in both national and international conferences on EFL teaching and learning. The last three articles she has written were: 1) Atti-tude toward Autonomy in Learning English: A Case in Cenderawasih University Papua, Indonesia, Asian EFL Journal/ Professional Teaching Articles. August (86), 2015; 2) Multilingual Lecturers' Competence in English Teaching at the University of Iqra Buru, Indonesia. Asian EFL Journal, 5, 2016; and 3) Mapping of the Competence of SHS Students in English Subject in Sarmi and Mamberamo Raya Regencies Papua, Indonesia. The Asian EFL Journal. TESOL Indonesia International Conference Edition, Vol.10, 2016. Her research interests are in the area of Teaching English as a Foreign Language and a Second Language and EFL Teachers' Professionalism.

Ms. Rinantanti is a secretary of Teachers Certification Program area 131 Papua and West Papua provinces, Indonesia, a member of Indonesian Education Scholars Association (ISPI), and an editor of Jurnal Ilmiah Kependidikan FKIP UNCEN Jayapura.

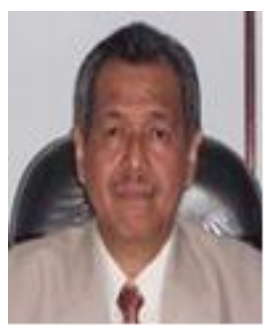

Muhammad Asfah Rahman was born in Selayar, South Sulawesi, Indonesia on May 21, 1952. He completed his undergraduate study in 1979 in Teaching English as a Foreign Language (TEFL) at Ujung Pandang Institute of Teacher Training and Education) in Makassar, Indonesia and master and doctorate degrees in the field of Instructional Design and Technology at the University of Pittsburgh, PA, USA in 1986 and 1990 respectively.

$\mathrm{He}$ is currently a professor in the Faculty of Literature and Language, State University of Makassar, in Makassar, Indonesia. He has a lot of experience in elementary and secondary school teacher training, teacher professional development, and teaching English to young learners.

He was employed for five years as ACADEMIC ADVISOR for USAID Decentralized-Basic Education leading university faculty members to develop active learning training packages for elementary school teachers. In the last couple of years, he did a research and a development study whose product is a training package for elementary school teachers of English. At present, his research focuses on module development for improving EFL college writing. He has got the Best Paper Awards on his article entitled "Reading in English as a Foreign Language: A Case of First Year Students of Junior Secondary Schools in South Sulawesi Indonesia" from the 2nd International Conference on Theory \& Practice (ICTP-2016) of Asia Pacific Institute Advanced Research. His research interests include early reading program for learners of English as a foreign language.

Prof. Rahman is a member of Indonesian Linguistics Society (MLI), Indonesian Education Scholars Association (ISPI), and TEFLIN (Teaching English as a Foreign Language in Indonesia). 


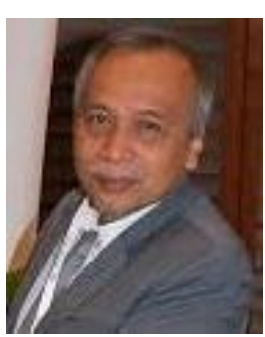

Haryanto Atmowardoyo was born in Purbalingga, Central Java, Indonesia on October 29, 1959. He is a professor of English Education at English Department of State University of Makassar, Indonesia. He completed his Elementary education in SD Galuh, Purbalingga in 1971, Junior High School at SMP Borroneus Purbalingga in 1974, and Senior High School at SMA Negeri Purbalingga in 1977. He completed his bachelor degree in 1977 and Master Degree in English education at IKIP Malang. He obtained his doctoral degree in English Education at IKIP Jakarta in 1999.

He participated in academic Recharging Program in OHIO State University, Columbus, OHIO, USA from Sepetember 2009 to January 2010. He has published several books : Isu Pendidikan dan Pengajaran Bahasa (2001), published by State University of Makassar Press; Dasar-Dasar Penulisan Proposal Penelitian (2008), a collaborative work with Sukandarrumidi, of Gajah Mada University, published by Gajah Mada Press (2008); and Metodology Penelitian Kualitatif; Teori Dasar (2008) published by State University of Makassar press. Some articles have also been published either in newspaper, in on line journal, or in printed scientific journals; Cara Mudah Belajar Bahasa Inggris, Lokalisasi Pengajaran Bahasa Inggris; Fisibilitas Lokalisasi Pengajaran bahasa Inggris; and perlukah Revolusi Pengajaran Bahasa Inggris published in Fajar and Pedoman Rakyat in 1994; Critical analysis on teacher's Made Test (performance, 1995); Laboratorium bahasa multilmedia dan Fungsinya dalam Pembelajaran Bahasa Asing (20050, Pendidikan Network).

Prof. Atmowardoyo has presented some papers in international conferences: Research Methods in TEFL; Grammatical Error in Indonesian EFL Learners' Writing (May 2007, Jakarta, Annual Linguistic Conferences of Atmajay University); A Lesson for International Journal (Hanoi, Vietnam, August 2010, the 8 the Asia TEFL Conference), Qualitative research in TEFL Studies ( Makassar, 2 nd ICOLE Conference, December 2010) and Learners' Perception on the Personal and Professional Competences of Effective and Ineffective EFL Teachers ( $21^{\text {st }}$ Century Academic Forum Conference, Harvard, University, Boston US in 2016

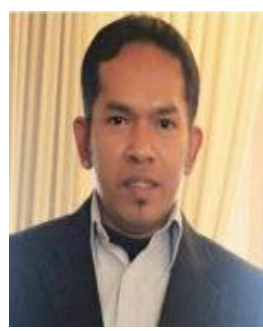

Saidna Z. Bin-Tahir was born in Ambon, Indonesia on June 11th, 1974. He is currently a doctoral candidate in English Education Department at the State University of Makassar. Indonesia. He graduated his BA from Al-Azhar University of Cairo in Arabic Language and Linguistics in 2006 and graduated his master degree in English Education Department of the State University of Makassar in 2012.

$\mathrm{He}$ is a lecturer at English Education Department of the University of Iqra Buru, Maluku, Indonesia. He has published some books for the last of three years including 1) Teaching English a World Language: Pengajaran Bahasa Inggris. Jakarta: Media Pustaka Qalam, 2013; 2) Multilingual Education in Pesantren Context, Yogyakarta: Deepublish, 2015. He also has published many articles in TEFL, ICT in language Learning and Multilingual teaching and learning such 1) Multilingual behavior of Pesantren IMMIM Students in Makassar, Asian EFL Journal, Vol 86, 2015; 2) Multilingual Teaching and Learning at Pesantren Schools in Indonesia, Asian EFL Journal, Vol. 98, 2017.

Mr. Bin-Tahir had become a member of Asia TEFL, reviewer and editor in some local and international journals and a head of the language center at the University of Iqra Buru. 